MATEC Web of Conferences 47, 05021 (2016)

DOI: $10.1051 /$ matecconf/20164705021

(C) Owned by the authors, published by EDP Sciences, 2016

\title{
Challenges in Selecting a Sustainable Landfill Site in Malaysia
}

\author{
Tey Jia Sin ${ }^{1, a}$, Goh Kai Chen ${ }^{1}$ and Goh Hui Hwang ${ }^{2}$ \\ ${ }^{1}$ Faculty of Technology Management and Business, Universiti Tun Hussein Onn Malaysia, 86400 Parit Raja, Johor, \\ Malaysia \\ ${ }^{2}$ Faculty of Electrical and Electronic Engineering, Universiti Tun Hussein Onn Malaysia, 86400 Parit Raja, Johor, \\ Malaysia
}

\begin{abstract}
Landfill is essential in the management of municipal solid wastes in Malaysia. The role of a landfill site has become prominent with the increasing quantity of municipal solid waste. However, the selection of a landfill site has always been one of the crucial yet complicated parts in constructing a landfill. Due to the negative impacts that caused by a landfill site, an appropriate landfill site is required in order to minimize the negative impacts to the lower. Therefore, this paper probes into the challenges in landfill site selection in Peninsular Malaysia. This research is conducted through the reviewing of past similar research and case study with eight different government departments that have play a role in evaluating the suitability of a site to be used as landfill. The results obtained show the challenges in selecting a landfill site. Through the understanding of the landfill site selection, it enables future research to improve the current landfill site selection system and ensure its sustainability.
\end{abstract}

\section{Introduction}

As the population and the generation of municipal solid waste increases simultaneously, Malaysia starts to realize that the need of a proper waste management system is required to cope with the daily quantity of municipal solid wastes produced. In 2007, the government established a new act which is known as Solid Waste and Public Cleansing Management Act, 2007. This act is used to provide proper guidelines and regulations, and a holistic approach to waste management [1]. The purpose of establishment of the act is for the transferring of executive authority from the local authority to the Federal Government. Through this act, the Department of National Solid Waste Management and the Solid Waste Management and Public Cleansing Corporation are operating throughout peninsular Malaysia and it imposes higher responsibilities on the stakeholders [2].

The generation of municipal solid wastes is more than 30,000 tonnes per day [3]. However, Malaysia shows a statistic that about $60 \%$ of the wastes generated are disposed into landfill in which at present, more than half of the existing landfills has reached its maximum capacity but the number of landfills are limited [4, 5]. Hence, a landfill site that is selected according to the concept of sustainability is necessary to mitigate the negative impacts towards human health and the environment. As a result, this paper focuses on revealing the challenges in selection of a landfill site in peninsular Malaysia.

\footnotetext{
${ }^{\text {a }}$ Corresponding author : jiasin.star@gmail.com
} 


\section{Waste Management}

As the waste management has been given more attention, many techniques are then utilized in the industry in managing wastes. Among the waste management techniques are, recycling, incineration and composting are the common approaches. Wastes generated must be reduced or reused, unless the waste generated cannot be recycled, then applying incineration or landfill is the last resolution [6, 7].

The sanitary landfill method for the ultimate disposal of solid waste material continues to be widely accepted and used in Malaysia at the present stage [8,9]. This is due to its economic advantages. Furthermore, landfill as compared to other disposal options, it requires less costs [8,9].

Besides, government faces the problem in selecting an appropriate landfill site. An appropriate site has to be environmental friendly, acceptable by the public and the least cost that require in managing wastes. There are tipping fees to be charged from the imported waste [10]. Thus, a simpler way in selecting a landfill site has to be identified so as to increase the accuracy of the end result.

\subsection{Development of municipal solid waste management}

Solid waste is defined as any scrap material or other unwanted surplus substance or rejected products arising from the application of any process or any substance required to be disposed of as being broken worn out, contaminate or otherwise spoiled [11].

As year pass by, Malaysia government has been putting effort in the improving of managing municipal solid waste that created daily by establishing Department of National Solid Waste Management and Public Management Corporation. The highly increasing of solid wastes as compare to the past, thus a holistic system and law in managing municipal solid waste need to be enforced in order to ensure the environment being protected.

\subsection{Landfill site selection}

Both Siting a landfill site plays an important role in contributing a sustainable landfill. The decision of optimizing landfill siting have gained considerable importance so the least damage impacts could be ensured towards to the various environmental aspects as well as to the individual who are living surround the landfill site, thereby enhancing overall sustainability associated with the life cycle of a landfill [12]. By virtue of these, the Malaysia government recognizes that the appropriate waste management is essential tool in achieving sustainable development [13].

In terms of economics aspects, the price of the land depreciates as it getting nearer to the landfill site [14]. The effects generated through the landfill are such as noise pollution, surrounding area are aesthetical unattractive, and also, air pollution. Other than that, construction and operation of landfill requires high capital cost [15].

In Malaysia, the landfill site selection process for the land which is owned by the federal government is done by the National Solid Waste Department. However the rest is owned by the state government or private companies. Once the site being selected, it will be executed by Solid Waste and Public Cleansing Management Department (PPSPPA). National Solid Waste Department holds the authority in the planning for the locating process whereby it has to be matched with the requirement set by the Department of Environment and Town Country Planning.

Currently, Malaysia is using geographic information system in the evaluation of a landfill site. It is a tool to speed up the site selection process by showing a clearer presentation of suitable and unsuitable sites based on the set of criteria given. However, geographic information system is not comprehensive enough; it is mainly due to the fact that evaluation criteria produced ultimately weak evidence to support the selection [16]. Thus, it leads to the need to develop a proper tool in the evaluation process for a site and ensure the criteria uses are fulfil sustainable concept. 


\subsection{Landfill site selection criteria}

Under Department of Environment in Malaysia, prior for a landfill site to be selected, it has to fulfill a series of criteria listed out to reduce the impacts towards the environment to the minimum. In relation to this, Department of Environment has produce a guideline namely, Guidelines for Development of Solid Wastes Sanitary Landfill. In this guideline, it stated six major criteria that should be taken into consideration when selecting a landfill site [17]. Among the six criteria are available area, surrounding environment and conditions, topography and geological conditions, transport infrastructure and access, post closure and land use plan, and availability of supplies.

Table 1. Impact of environmental impact assessment criteria towards landfill site selection.

\begin{tabular}{|c|c|}
\hline Criteria & Influence towards Landfill Site Selection \\
\hline Available area & $\begin{array}{l}\text { An appropriate landfill site is the one having sufficient area to cater municipal solid } \\
\text { wastes up to } 20 \text { to } 25 \text { years, besides, the area have to include with landfill facilities and } \\
\text { buffer zone [17]. A landfill with short lifespan will cause the search of a new landfill site } \\
\text { to be done in short period of time. } \\
\text { Due to the land in Malaysia is getting scarce, a high cost is needed in acquisition a land } \\
\text { [18], it becomes tougher for the searching of an appropriate land to be used as landfill } \\
\text { site. }\end{array}$ \\
\hline $\begin{array}{l}\text { Surrounding } \\
\text { environment/ } \\
\text { Conditions }\end{array}$ & $\begin{array}{l}\text { The environment of the surrounding have to take into consideration. It is necessary to } \\
\text { ensure over the place has basic utilities supply, and the proximity to rivers and water } \\
\text { intake point [17]. The bacis utilities is requires to make sure the landfill can be operating } \\
\text { well while avoiding water area is to prevent leachate contaminate the water. } \\
\text { The negative effects left from the landfill site such as noise, pollution will caused the } \\
\text { land price surround the landfill site depreciate [14]. Thus, it is highly important to select } \\
\text { a landfill where it can lower the possible chance to bring negative effect the surrounding } \\
\text { area. }\end{array}$ \\
\hline $\begin{array}{l}\text { Topography } \\
\text { and geological } \\
\text { conditions }\end{array}$ & $\begin{array}{l}\text { The geology of an area will directly control the types of soil created from the parent } \\
\text { material, load bearing capacity of the landfill's foundation soil, and the mitigation of } \\
\text { leachate [10]. } \\
\text { A good landfill site is the one that can reduce the need in of doing serface earthworks. } \\
\text { The area which is prone to flood should be avoid in use as landfill site as well [17]. }\end{array}$ \\
\hline $\begin{array}{l}\text { Transport } \\
\text { infrastructure } \\
\text { and access }\end{array}$ & $\begin{array}{l}\text { A good landfill site has to locate away from the residential area, but not isolated. The } \\
\text { easy accessible of the waste vehicles will enable emergency helps in case of accidents } \\
\text { happan on site [17]. } \\
\text { On the other hand, the distance of the municipal solid wastes generation and landfill site } \\
\text { will affect the transport cost directly [10]. }\end{array}$ \\
\hline $\begin{array}{l}\text { Post closure } \\
\text { land use plan }\end{array}$ & $\begin{array}{l}\text { It is essential for the authority to plan for the post closure land use for the landfill site } \\
\text { before a land is gazetted for landfill use. This is a close landfill site will still produce } \\
\text { gases which is not good for human body and it is ideally not suitable for residential } \\
\text { purpose [17]. To select a good landfill site has to consider the impact not only during the } \\
\text { landfill site operating but also post closure land use plan. }\end{array}$ \\
\hline $\begin{array}{l}\text { Availability of } \\
\text { supplies }\end{array}$ & $\begin{array}{l}\text { Observing and identifying the materials that can be provided from the surrounding of the } \\
\text { land is necessary as it can helps to reduce huge cost of transporting and purchasing of the } \\
\text { materials from afar [17]. One of the example is cover soil that is use in landfill site. }\end{array}$ \\
\hline
\end{tabular}

From Table 1, it can be seen that the environmental impact assessment criteria in landfill site selection is still focusing more on the environmental criteria whereas on the economic and social part is giving lesser emphasis. This makes the whole evaluation of a selection of a landfill site become not holistic. Hence, the site that selected might be able to reduce the negative impacts towards the environment but it may incur higher cost for the people in charge or has the authority. 
This paper employed literature review and qualitative case study as the research methods to gather a more in- depth information from eight of the government sectors which involves in the evaluation of landfill site selection. This research was done through the qualitative case studies in which it has eight respondents from different government departments. Among the departments are Department of National Solid Waste Management, local authorities, State Economic Planning Unit, Public Work Department, Department of Environment, Town and Country Planning Department, Department of Irrigation and Drainage, and Solid Waste Management and Public Cleansing Corporation.

The current waste management methods adopted by Malaysia were identified. Besides, the problems faced during the landfill site selection are being discussed. This research is expected to improve current condition in landfill site selection by identifying the challenges. The concept of sustainability is desire to be implemented in the consideration of a suitable land to turn it into a landfill site. Thus, the perspective of each respondent which represents each government sector is determined in this research as well.

\section{Results and Discussion}

\subsection{Challenges in landfill site selection}

According to El Haggar [15], selecting a site for landfill purpose is one of the very significant processes to reduce the negative impacts to the surrounding. In Malaysia, the landfill site selection process for the land which is owned by the federal government is done by the National Solid Waste Department. However, the rest is owned by the state government or private companies. Once the site being selected, it will be executed by Solid Waste and Public Cleansing Management Department.

\subsubsection{Limited area}

According to the respondents, there are many criteria has to consider for a site to be chosen as the landfill site. A thorough examination needs to carry out and the potential landfill site is limited as not all the lands are suitable to be used as landfill site. Thus, although there are many lands in Malaysia, however, not every land is suitable for the development of a landfill site. Furthermore, some authorities in Malaysia hardly select a land to be used as landfill because the land is getting scarce and high cost is required in acquisition a land [18].

\subsubsection{Non standardisation in selection criteria}

Moreover, the identification of landfill sites for municipal solid waste disposal becomes a critical management issue in which it requires a number of considerations before the implementation to reduce the impacts it may cause to the individual [19]. This makes the decision makers face difficulties in weighing the factors in the selection of a landfill site as to reduce the negative impacts that may bring to the surrounding. Factors that are in the consideration are such as environmental, social and economic aspects.

However, according to the respondent, currently Malaysia has yet to come out general sustainable criteria as guideline for the selection of a landfill site to be sustainable. Most of the criteria that have been taking as consideration is environmental aspect because of the leachate as a by- product from landfill. It may be a challenge for a landfill site that is selected fulfill the concept of sustainability. 


\subsubsection{Politics (public against landfill)}

According to respondent, politics in social aspect plays an important role in determining the construction of a landfill at a selected site. There are times where the suitable site has been selected, but the objection by the public will cause the project unable to be carried out.

In addition, in Malaysia, it is getting tougher to locate a suitable landfill site as each individual is possessing the attitude of not in my backyard and not willing to accept the implementation of a new landfill site, especially the landfill is near to the residential area with the reason of pollution, unpleasant smell and littering may happen in the future [20].

\subsubsection{Technology selection}

The adoption of an incinerator in Malaysia is still not being widely used based on the respondents. Some of the incinerators constructed by the Ministry of Urban Wellbeing, Housing and Local Government are yet to operate as well as they fail in terms and conditions. Besides the capital expenditures and operate expenses are very high as compare to landfill. Thus, landfill is still required in managing the solid wastes generated and a sustainable site should be selected.

On the other hand, currently Malaysia is only selects a landfill site through geographic information system. Geographic information system was employed by consultants under the Department of National Solid Waste in the evaluation of a site base on the criteria given. However, geographic information system is not comprehensive enough [16]. It leads to the needs of a more effective model to analyse the criteria and ensure a site that is sustainable to be chosen.

In addition, some of the respondents also highlighted that Malaysia is still lacking of the selection technology as the characteristic of municipal solid wastes are very different with other countries. In Malaysia, the wastes collected is damp and it unable to be decompose using the same technique as other countries. The more municipal solid wastes dump into a landfill, the faster the land become full and increase the need to select a new land for new landfill.

\subsubsection{The application of sustainable concept into landfill site selection}

Sustainable landfill is crucial in a waste management system as it can reduce the potential risk to the environment [21]. According to the respondents, not all aspects in sustainable will be considered in the evaluation of a site to become a landfill. Some of the government sector is only emphasizing on environmental aspects such as on the buffer zone however, the cost of transportation for sending municipal solid wastes to landfill from the origin has been put it aside. It caused a great problem as the site selected may be bringing an advantage for the environment and social aspects. On the other hand, it may incur high cost on the landfill management, which is not sustainable concept in landfill site selection. Hence, the results have shown a need in generating a better way of landfill site selection as the practitioner has yet to fully apply the concept of sustainability.

\section{Conclusion}

This paper has pointed out the best suitable Malaysia waste management treatment technique, landfill in the near future, and its challenges in the selection of the site. Waste management is an important sector because the municipal solid wastes will not stop generating due to the waste management system is not ready in a country. The challenges mentioned in previous lead to the need of having a decision model in evaluating the most suitable land base on a set of sustainable landfill site selection criteria. As the area for the land to be used as landfill is limited, the improvement in landfill site selection through a better system which considers the sustainable criteria will definitely brings a great benefit not only to the government sector but also to each individual in Malaysia. The upgrading of the landfill site selection system can speed up and increase accuracy in choosing a sustainable site which emphasing at all environmental, social and economic aspects. 


\section{Acknowledgement}

The authors express gratefully acknowledgement to the industry stakeholders for their valuable contributions towards success of this research. This research is fully funded by UTHM.

\section{References}

[1] N.S. Romali, N. Mokhtar, W.F.W. Ishak and M.A.A. Samah, Solid waste management: Development of AHP model for application of landfill sites selection in Kuantan, Pahang, Malaysia, Proc. of the Int. Symposium on the Analytic Hierarchy Process, Kuala Lumpur, (2013).

[2] N. Yahaya and I. Larsen, Federalising solid waste management in peninsular Malaysia, Proc. of Int. Solid Waste Association (ISWA) World Congress, Singapore, (2008).

[3] P. Agamuthu and S. Fauziah, Challenges and issues in moving towards sustainable landfilling in a transitory country-Malaysia, Waste Management and Research, 29,13-19, (2011).

[4] F.M. Ghazali, S. Syafalni and S.M. Noor, Public perception on the current solid waste management system in Malaysia: A comparative study of Matang Landfill and Bukit Tagar Sanitary Landfill (BTSL), World Applied Sciences J., 32, 872-883, (2014).

[5] A. Johari, S.I. Ahmed, H. Hashim, H. Alkali and M. Ramli, Economic and environmental benefits of landfill gas from municipal solid waste in Malaysia, Renewable and Sustainable Energy Reviews, 16, 2907-2912, (2012).

[6] M.O. Saeed, M.N. Hassan and M.A. Mujeebu, Assessment of municipal solid waste generation and recyclable materials potential in Kuala Lumpur, Malaysia, Waste Management, 29, 22092213, (2009).

[7] O. Ortiz, J. C. Pasqualino and F. Castells, Environmental performance of construction waste: Comparing three scenarios from a case study in Catalonia, Spain, Waste management, 30, 646654, (2010).

[8] Z.Z. Noor, R.O. Yusuf, A.H. Abba, M.A. Abu Hassan and M.F. Mohd Din, An overview for energy recovery from municipal solid wastes in Malaysia scenario, Renewable and Sustainable Energy Reviews, 20, 378-384, (2013).

[9] N.P. Cheremisinoff, Handbook of Solid Waste Management and Waste Minimization Technologies, Butterworth-Heinemann, Elsevier Science, (2003).

[10]B. Şener, M.L. Süzen and V. Doyuran, Landfill site selection by using geographic information systems, Environmental Geology, 49, 376-388, (2006).

[11] Solid Waste and Public Cleansing Management Act 2007, Putrajaya, (2007).

[12] V.R. Sumathi, U. Natesan and C. Sarkar, GIS-based approach for optimized siting of municipal solid waste landfill, Waste Management, 28, 2146-2160, (2008).

[13]E. Papargyropoulou, D.C. Preece, D.R. Padfield and A.A.B. Abdullah, Sustainable construction waste management in Malaysia: A contractor's perspective, Proc. of the Int. Conf. on Management and Innovation for a Sustainable Built Environment, Amsterdam, (2011).

[14] S.K. Jung, An integrative approach for municipal solid waste (MSW) landfill selection: A case study of O'ahu, Hawai'i, PhD Thesis, University of Hawai'i at Manoa, Ann Arbor, (2011).

[15]S. El Haggar, Sustainable Industrial Design and Waste Management: Cradle-to-Cradle for Sustainable Development, Academic Press, Elsevier, (2010).

[16] S.N.S. Ismail and L.A. Manaf, The challenge of future landfill: A case study of Malaysia, J. of Toxicology and Environmental Health Sciences, 5, 86-96, (2013).

[17] Department of Environment, Environmental Impact Assesement-Guidelines for Development of Solid Waste Sanitary Landfill, Department of Environment, Malaysia, (2012).

[18]Z. Sakawi, Municipal solid waste management in Malaysia: Solution for sustainable waste management, J. of Applied Sciences in Environmental Sanitation, 6, 29-38, (2011).

[19]E. Suresh and N. Usha, GIS modelling of land suitability for solid waste disposal, Int. J. of Geoinformatics, 4(3), (2008). 
[20]U.N. Ngoc and H. Schnitzer, Sustainable solutions for solid waste management in Southeast Asian countries, Waste Management, 29, 1982-1995, (2009).

[21] S. Fauziah and P. Agamuthu, Trends in sustainable landfilling in Malaysia, a developing country, Waste Management and Research, 30(7), 656-663, (2012). 